\title{
The Effect of Gamma Irradiation on the Growth and Multiplication of the In Vitro Shoot of Patchouli (Pogostemon cablin Benth.)
}

\author{
Yunia Efrice Banyo, Serafinah Indriyani, Wahyu Widoretno* \\ Department of Biology, Faculty of Mathematics and Natural Sciences, University of Brawijaya, Malang
}

\begin{abstract}
The objective of this research was to evaluate the effect of gamma irradiation on shoot growth and multiplication of Patchouli (Pogostemon cablin Benth.) Two weeks-old in vitro shoots were irradiated gamma-ray, at doses of 0, 15, 30, 45, 60, and 75 Gy. The control shoot was not irradiated. The irradiated shoots were cultured on Murashige and Skoog (MS) medium supplemented with $0.1 \mathrm{mg} \cdot \mathrm{L}^{-1} \mathrm{NAA}$ and $0.3 \mathrm{mg} \cdot \mathrm{L}^{-1} \mathrm{BA}$ and incubated in a growth room for eight weeks at a temperature of $25 \pm 2^{\circ} \mathrm{C}$. The results showed that the gamma irradiation inhibited the growth and multiplication of shoots. Explants irradiated with high-dose gamma-ray (45-75 Gy) had not formed shoot in four weeks of culture, while 58.3-83.3\% of the explants without irradiation or irradiated at low doses 15 and $30 \mathrm{~Gy}$ formed shoots. The higher irradiation doses increased percentage of browning explants and reduced the percentage of forming shoots. Within the eight weeks of culture, explant without irradiation was able to form shoots at the percentage of $100 \%$ with 24 shoots per explant, while explants irradiated at $15-45 \mathrm{~Gy}$ were able to grow form shoots at the percentage of $77.7-95.5 \%$. The high doses-irradiated explants ( 60 and $75 \mathrm{~Gy}$ ) were only able to form shoots less than $13-20 \%$, with $2-3$ shoots per explant.
\end{abstract}

Keywords: Gamma rays (Gy), in vitro shoot, Pogostemon cablin Benth.

\section{INTRODUCTION}

Patchouli (Pogostemon cablin Benth.) is one of the essential oil-producing plants. The oil is mostly found in its leaves [1]. Essential oil forms this plant is universally recognized as the best because it is the material for the food, pharmacy, and cosmetic industry [2]. Indonesian Plantation Service recorded that patchouli plantation in the country covers an area of 18,841 ha, producing 2,115 tons patchouli oil [3]. The annual demand for the oil is $60 \%$, around $700-2,800$ tons. Indonesian export is estimated to be $80 \%$ of the world's export [4].

Industrial development has made both domestic and international demand for Patchouli oil increase [5]. One of the ways to increase oil production is developing genetic variations for quality seeds through mutation induction; one of the techniques is gamma-ray mutagen treatment [6]. Successful experiments to increase essential oil content and secondary metabolites are those in Boswellia carterii [7], orange peel [8], and ginger (Zingiber officinale Roscoe) [9]. Gamma irradiation of 30-100 Gy on in vitro shoot explants can produce variations in Eustoma grandiflorum and banana (Musa spp.) $[10,11]$. Gamma-ray also affects shoot growth of Strawberry [12] banana [13] and inhibited root growth in Rubus fraxinifolius [14]

* Correspondence address:

Wahyu Widoretno

Email : wahyu_widoretno@yahoo.com

Address : Dept. Biology, University of Brawijaya, Jl. Veteran Malang, 65145 under in vitro conditions. The objective of this research was to evaluate the effect of gamma irradiation on the growth and multiplication of in vitro patchouli shoot explants.

\section{MATERIALS AND METHODS \\ Plant material}

In vitro shoots of Patchouli cv. Lhokseumawe were derived from laboratory's collection. In vitro shoots were propagated on MS mediumsupplemented $0.1 \mathrm{mg} \cdot \mathrm{L}^{-1} \mathrm{NAA}$ and $0.3 \mathrm{mg} . \mathrm{L}^{-1} \mathrm{BA}$. Two weeks old in vitro shoots were used as explant for gamma-ray irradiation.

\section{Gamma irradiation of in vitro shoot cultures.}

The gamma irradiation was carried out at National Nuclear Energy Agency, Jakarta, Indonesia. Two weeks old in vitro shoot of approximately $1 \mathrm{~cm}$ in length were exposed to gamma radiation at different doses of gamma-rays $(0,15,30,45,60$, and $75 \mathrm{~Gy})$. These doses based on previous research on Coleus blumei to obtain new Coleus variances in a relatively short time [15]. The source of gamma rays was ${ }^{60} \mathrm{Co}$ gamma irradiatorGamma Cell 220 at a dose rate of 4585.5 Grey/minute. After irradiation, treated shoots were immediately transferred to a fresh MS medium containing $0.1 \mathrm{mg} . \mathrm{L}^{-1} \mathrm{NAA}$ and $0.3 \mathrm{mg} \cdot \mathrm{L}^{-1} \mathrm{BA}$. Fives shoots were cultured in each culture bottle, and ten replicated were conducted for each gamma-ray dose (Fig. 1).

The culture was incubated at a temperature of $25 \pm 2^{\circ} \mathrm{C}$ and $16 \mathrm{~h}$ day/8h dark photoperiod at the light intensity of 600 lux in a growth room for 8 
weeks. Percentage of browning explants and shoot formation; number and length of shoot were observed every four-week. Analysis of variance (ANOVA) followed by the LSD test was used to determine the differences in mean number of all tested parameters between irradiation doses.

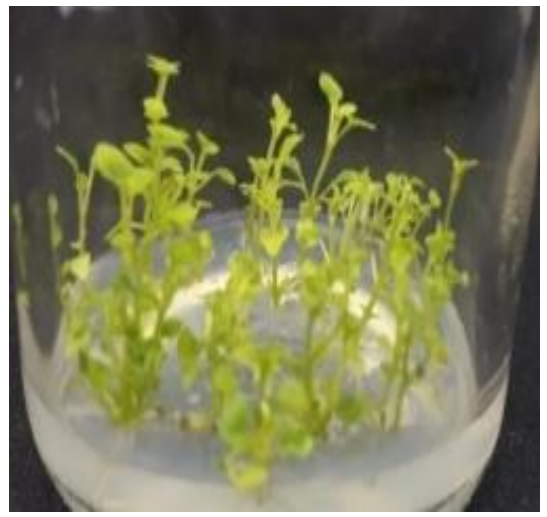

Figure 1. In vitro shoots used as explant for gamma ray irradiation

\section{RESULTS AND DISCUSSIONS}

The Gamma-irradiation on in vitro shoot explants affected the shoot growth and multiplication of patchouli. Irradiation at the doses 15-75 Gy caused browning on the shoot tip apical meristem and made the leaf yellowish. The higher the dose of irradiation, the higher was browning of explant. Gamma-ray irradiation on shoot explants also inhibited the growth of explants and the formation of new shoots. The inhibition of growth and multiplication of irradiated shoot increased as the gamma dose increased (Fig 2).

Gamma irradiation on in vitro shoot can increase the percentage of shoot browning and decrease shoot-forming explants. The effects of doses of gamma rays on shoot growth and formation of the new shoot during eight weeks in culture are shown in Figure 3. Gamma irradiation on shoot explant increased the percentage of shoot browning and decreased shoot-forming explant percentage, number, and length of the shoot. The browning percentage of irradiated shoot increased as the gamma dose increased.

The irradiation at the doses 15-75 Gy increased the percentage of browning $8.3-36.6 \%$ in four weeks of culture and $15.5-62 \%$ in eight weeks culture, while the shoot without irradiation (control) showed no browning (Fig. 3A). Gamma irradiation on shoot explant inhibited shoot growth and formation of a new shoot. Percentage of shoot formation and number shoot per explant of irradiated shoot explant decreased as the gamma dose increased (Fig. 3B and 3C). In four weeks of culture, the explant irradiated at higher doses of gamma rays (45-75 Gy) had not formed shoot, whereas more than $83.3 \%$ of non-irradiated explant (control) formed new shoot and 58.3-67\% of irradiated explant at lower doses (15-30 Gy) formed shoot. The ability to form shoots of nonirradiated explants was ten shoots per explant, whereas at lower doses of gamma rays (15-30 Gy) was less than five shoots per explant.

Irradiation of gamma-ray also reduced the number of regenerated shoots per explant. The number of regenerated shoots reduced prominently with the increase in gamma irradiation dose. The number of regenerated shoots per explant was significantly lower at higher doses (6075 Gy). However, at lower doses (15-45 Gy) was slightly decreased compared to control (Fig. 3C). In eight weeks of culture, $100 \%$ of non-irradiated explant produced shoot with 24 shoots per explant, while irradiated explant at lower doses of gamma rays (15-45 Gy) formed shoot was $67-77.7 \%$ with 720 shoots per explant.
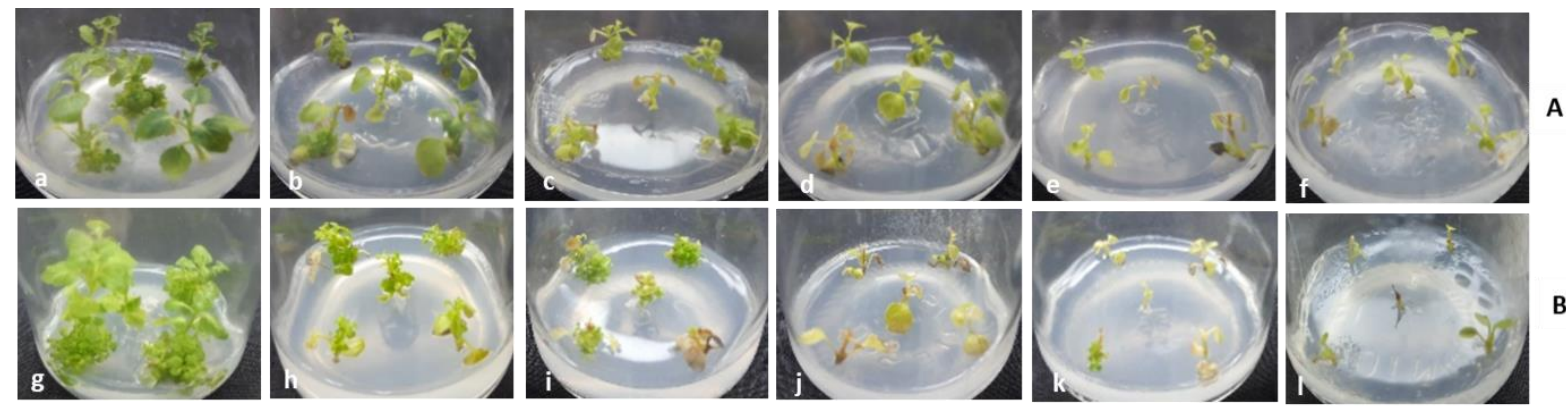

Figure 2. The responses of patchouli's in vitro shoot toward gamma irradiation. A. Explants were cultures for four weeks. B. Explants were cultures for eight weeks. Description: a,g: 0 Gy (control), b,h: 15 Gy, c,i: 30 Gy, d,j: 45 Gy, e,k: 60 Gy, f,l: 75 Gy. 


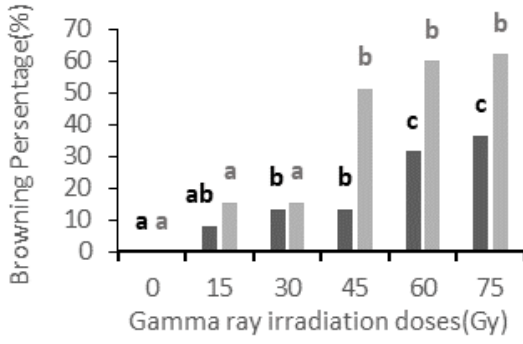

A

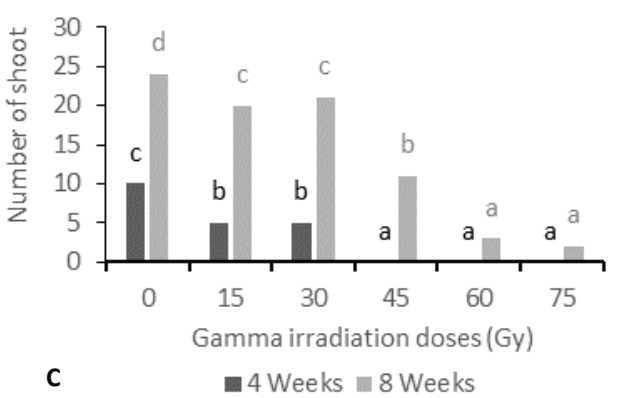

Figure 3. The effect of Gamma ray Irradiation on browning percentage, shoot-forming explant percentage, number and length of patchouli's in vitro shoots after 4-8 weeks of culture. Notes: the same letter in each observation parameter indicates insignificant difference according to $5 \%$ Duncan test.
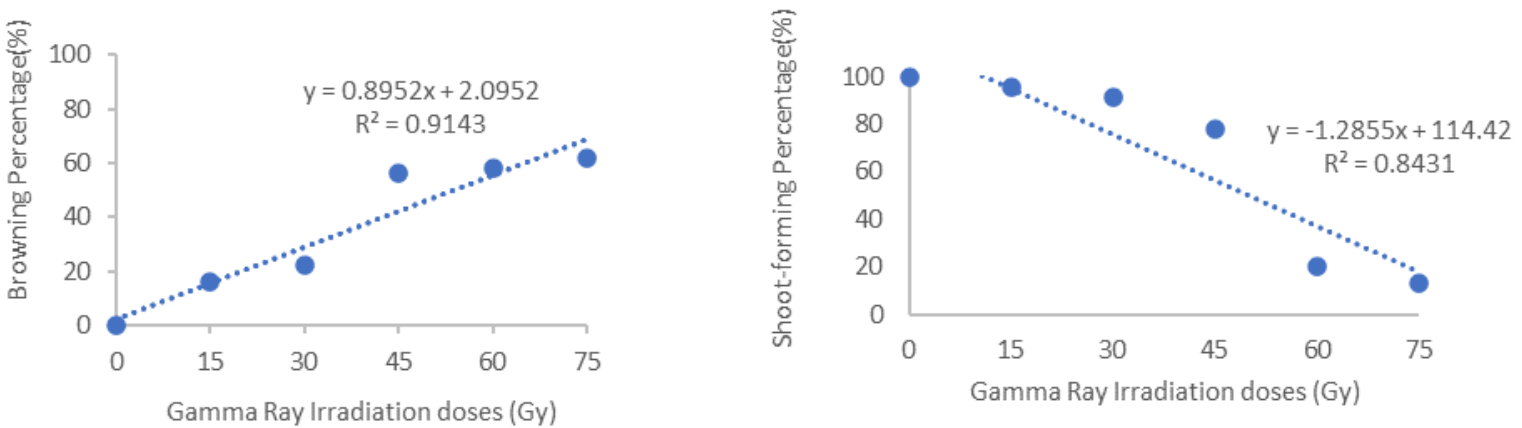

Figure 4. Correlation between gamma-ray irradiation doses and explant browning percentage and shoot-forming explant percentage

Shoot forming percentage of higher irradiated explant (60-75 Gy) was only $13-20 \%$, with 2-3 shoots per explant (Fig. 3B and 3C). Beside shoot formed was lower, shoot growth of irradiated explant was also inhibited. The shoot length reduced with an increase in gamma irradiation doses (Fig. 3D). Shoot height growth at 8 weeks in the culture of explant without gamma-ray irradiation was about $1 \mathrm{~cm}$, while shoot height growth of explant irradiated with gamma rays at doses of 15-45 Gy was between 0.3-0.6 cm. Shoot growth of explants that were irradiated by $60-75$ Gy was only about $0.2 \mathrm{~cm}$ (Fig. 3D).

Analysis of the correlation between gamma-ray irradiation and the percentage of browning explant and the percentage of shoot forming obtained correlation coefficient $R$ values of 0.9143 and 0.8431 , respectively. There was a positive correlation between the dose of gamma-ray irradiation and the percentage of browning explants and a negative correlation between the dose of gamma-ray irradiation and the percentage 
of shoot forming. This indicated that the increasing in the percentage of browning explant and the decreasing in the percentage of shoot formation were in line with the increase of gamma doses (Fig. 4). Gamma-ray irradiation on plant tissue caused browning and inhibited the growth and formation of a new shoot. Previous research found that explant browning caused by gamma irradiation was due to the degradation of indole acetic enzyme, which plays a role in the synthesis of IAA. The enzyme degradation produced browning of explants [16]. Browning is caused by phenol oxidation after cell membrane degradation or cell disorganization followed by chlorophyll degradation. This process is an indicator of the formation of quinones as a result of the enzyme activity [17]. Effect of gamma irradiation on explant browning also observed on shoot explant of Colocasia esculenta (L.) Schott [18], callus of Ferula gummosa [19], and plantlet of Gerbera jamesonii [20]. A previous study observed the effect of gamma irradiation on in vitro total phenolic content of Ferula gummosa. The research showed that the gamma irradiation-induced phenolic compound in Ferula gummosa callus and phenolic content increased with the increased gamma irradiation dose [19].

Cell damage from high doses of irradiation is thought to be the cause of the growth and development of Robusta BP 436 coffee to be inhibited. The inhibition of growth and development is indicated by the black callus, which indicates necrosis (cell death). High doses of gamma-ray irradiation produce free radicals in the hydroxyl form. Hydroxyl radicals or hydrogen peroxide will cause physiological damage in the form of inhibition of cell division and differentiation processes and gene damage if these hydroxyl radicals attach to the nucleotide chains causing DNA damage [21].

Callus of Sugarcane (Saccharum officinarum L.) irradiated with gamma-ray doses $10-80$ Gy cause browning at a dose of $40 \mathrm{~Gy}$, and the extent of browning also increased with the increase of gamma irradiation dose [22]. Callus of Cucumis irradiated with a high-doses of 100-200 Gy experienced browning due to the absorption of gamma-ray irradiation that could increase free radicals, which damaged many cells in the callus [23]. High irradiation doses can change the ratio of the phytohormones auxin and cytokinin. It leads to the pattern change of cell differentiation, which could cause delays production of new shoots [24].

Irradiation-induced inhibition of shoot growth was caused by damage in meristem cells. The effect of irradiation was the inhibition of cell division, which results in inhibition of explant growth. Inhibition of shoot growth at higher doses of gamma rays is due to reduced mitotic activity in the meristematic tissue and reduced moisture contents of explants [25]. Chauduri also reported that irradiation at higher doses killed meristematic cells and result in the inability of the cells to absorb nutrients [26]. The inhibitory effect of the high dose of gamma rays on shoot growth was due to disruption of hormonal balance and enzymatic activities [27]. Irradiation does influence water intake to cells and the synthesis of endogenous hormones [20]. Inhibition of shoot growth due to the high dose of gamma rays was derived from cell cycle arrest at $\mathrm{G} / \mathrm{M}$ phase during cell division and/or various damages in the entire genome [28].

Gamma irradiation inhibited in vitro shoot elongation of patchouli. Effect of gamma irradiation on inhibition of shoot length was observed in Triticum aestivum L. [29] Cicer [30], Corn [31], and Chrysanthemum [32]. Gamma irradiation prevented the shoot elongation of Cicer. The effect of gamma irradiation on shoot elongation was depending on the dose of gamma and genotype, respectively. The higher irradiation, shoot length was more affected [30]. Previous research found that gamma irradiation decreased the number of leaves and branches on Chrysanthemum [32]. Gamma-ray irradiation also had a significant impact on the shoot length of Triticum aestivum $\mathrm{L}$. The shoot length decreased by $46 \%$ as the gamma dose increased [29]. It was observed that a decrease in shoot length is in proportion with increasing gamma dose in corn [31]. It was assumed that suppressed growth of explant tissue was caused by damage from irradiation treatment.

\section{CONCLUSION}

Gamma-ray irradiation on patchouli in vitro shoot inhibited shoot growth and multiplication. The irradiation of gamma rays at doses 15-75 Gy increased the browning percentage of explant and inhibited shoot formation. The percentage of shoot-forming explant, the numbers of shoots per explant, and shoot length decreased as the gamma-ray dose increased. 


\section{REFERENCES}

[1] Ermaya, D., S.P. Sari, A. Patria, F. Hidayat, F. Razi. 2019. Identification of patchouli oil chemical components as the results on distillation using GC-MS. IOP Conf. Earth and Environmental Science. 365. 012039.

[2] Sufriadi, E., Y. Aisyah, F. Harahap, Y. Fernando, V.Mardina. 2020. A method for aseptic culture of bud explants pogestemon cablin Benth. Var Tapak Tuan, Aceh, Indonesia. IOP Conf. Materials Science and Engineering. 725. 012066.

[3] Suhesti, S., M. Susilowati, N. Sirait, Amalia, E. Hadipoentyanti. 2020. Morphological variations of putative patchouli mutants. $I O P$ Conf. Earth and Environmental Science. 418. 012078.

[4] Lisma Y., L.M. Baga, Burhanuddin. 2018. Internal and external strategies in improving the value of patchouli agro industry case study of Koperasi Industri Nilam Aceh Barat. Jurnal AGRISEP. 17. 163-174.

[5] Habiburrohman, H., H.I. Agasi, L. Bernadetta. 2019. Preliminary design of high-yield patchouli (Pogostemon cablin Benth.) oil production system with phosphate fertilizer treatment and nutrient rich biomass production from black soldier flies (Hermetia illucens) larvae by applying a biorefinery concept. UI Proceedings on Science and Technology. 2. 48-52.

[6] Togatorop, E.R., S. I. Aisyah, M.R.M. Damanik. 2016. Effect of physical mutation by gamma ray irradiation on genetic variability and performance of Coleus blumei. J. Hort. Indonesia. 7. 187-194.

[7] Badr P., S. Daneshamouz, A.A. Mohammadi, A.R. Akbarizadeh, S. Afsharypuor. 2016. The effect of ${ }^{60} \mathrm{Co}$-gamma radio-sterilization on Boswellia carterii essential oil composition. Res. J. Pharmacogn. 3. 67-74.

[8] Moussaid M., S. Caillet, J. Nketsia-Tabiri, C. Boubekri, M. Lacroix. Effects of irradiation in combination with waxing on the essential oils in orange peel. 2004. J. Sci. Food Agric. 84. 1657-1662.

[9] Magdy M.A., E.M. Fahmy, Abd EL-Rahman M.F. AL-Ansary, G. Awad. 2020. Improvement of 6-gingerol production in ginger rhizomes (Zingiber officinale Roscoe) plants by mutation breeding using gamma irradiation. Appl. Radiat. Isot. 162. 109-193.

[10] Abou-Dahab, A.M., A.A.M. Heikal, L.S. Taha., A.M.M. Gabr, S.A. Metwally, A.A.R. Ali. 2017. In vitro mutagenesis induction in Eustoma grandiflorum plant using gamma radiation. J. Environ. Sci. Technol. 10. 175-185.

[11] Due, M.S., A. Yunus, A. Susilowati. 2019. Banana diversity (Musa spp.) resulted from in vitro gamma ray irradiation based on morphological markers. Proceeding of National Seminar of Masyarakat Biodiversitas Indonesia. 5. 2407-8050.

[12] Gupta R., V.K. Wali, P. Bakshi, G. Singh, R.A. Shah, S. Rani. 2018. Effects of gamma irradiation on shoot, root and survival percent in strawberry cv. Chandler under In vitro Conditions. Int. J. Curr. Microbiol. App. Sci. 7. 1173-1182.

[13] Abdulhafiz F., F. Kayat, S. Zakaria. 2018. Effect of gamma irradiation on the morphological and physiological variation from In vitro individual shoot of banana cv. Tanduk (Musa spp.). J. Plant Biotechnol. 45. 140-145.

[14] Ismaini L., S. Normasiwi, M.I. Surya, Destri. 2018. Study on in vitro growth of Rubus fraxinifolius mutant (m1) resulted from gamma-ray irradiation $\left({ }^{60} \mathrm{Co}\right)$. J. Agro Sci. 6. 71-76.

[15] Aisyah S. I., Y. Marthin, M. Rizal, M. Damanik. 2015. Improving performance of coleus through mutation induction by gamma ray irradiation. J. Trop. Corp. Sci. 2. 26-32.

[16] Lisdyayanti N.D., S. Anwar, A. Darmawati. 2019. Effect of gamma ray irradiation on callus induction and selection of rice tolerance level (Oryza sativa L.) on salinity stress by InVitro. Berkala Bioteknologi. 2. 67-75.

[17] Laukkanen, H., L. Rautiainen, E. Taulavuori, A. Hohtola. 2000. Changes in cellular structures and enzymatic activities during browning of Scots pine callus derived from mature buds. Tree Physiol. 20. 467-475.

[18] Brain, B., J. Stuar. 2019. Developing somaclonal variation of bogor taro to expand the diversity of character. CCAMLR Sci. 26. 5055.

[19] Sheikhi A.A., H. Hassanpour, P. Jonoubi, M.G. Nohooji, M. Nadimifar. 2016. The effect of gamma irradiation on In vitro total phenolic content and antioxidant activity of Ferula gummosa Bioss. J. Med. Plants. 159. 122-131.

[20] Hasbullah N.A., R.M. Taha, A. Saleh, N. Mahmad. 2012. Irradiation effect on in vitro organogenesis, callus growth and plantlet 
development of Gerbera jamesonii. Hortic. Bras. 30. 252-257.

[21] Ibrahim M.S.D., E. Randriani, L. Sari, A. Nuraini. 2019. Radiosensitivitas kalus embriogenik kopi robusta Bp 436 terhadap iradiasi sinar gamma. J. Industrial Beverage Crops. 6. 41-50.

[22] Nikam A.A., R.M. Devarumath, A. Ahuja, H. Babu, M.G. Shitole, P. Suprasanna. 2015. Radiation-induced in vitro mutagenesis system for salt tolerance and other agronomic characters in sugarcane (Saccharum officinarum L.). The Crop Journal. 1. 46-56.

[23] Venkateshwarlu, M. 2008. Effect of gamma rays on different explants of callus treatment of multiple shoots in Cucumis melo cv. Bathasa. J. Environ. Biol. 29. 789-792.

[24] Roostikal., I. Darwati, Yudiwanti. 2013. Improvement of genetic variation of Pruatjan through gamma irradiation and in vitro selection. Jurnal Littri. 19. 88-98.

[25] Majeed, A., Muhammad, Z., Ahmad, H. and Khan, A. U. R.2009. Gamma Irradiation Effects on Some Growth Parameters of Lepidium Sativum L. American-Eurasian J. Sustai. Agri. 3. 424-427.

[26] Chauduri, K.S. 2002. A reliable and straightforward method to detect gamma irradiated lentil (Lens culinaris Medik.) seeds by germination efficiency and seedling growth test. Radiat. Phys. Chem. 64. 131-136.

[27] Wi, S.G., B.Y. Chung, J.S. Kim. 2007. Effects of gamma irradiation on morphological changes and biological responses in plants. Micron. 38 . 553-564.

[28] Preussa, S.B., A.B. Britta. 2003. A DNAdamage-induced cell cycle checkpoint. Arabidopsis Genetics. 164. 323- 334.

[29] Borzouei, A., M. Kafi, H. Khazaei, B. Naseriyan, A. Majdabadi. 2010. Effects of gamma radiation on germination and physiological aspects of wheat (Triticum aestivum L.) seedlings. Pak. J. Bot. 42. 2281-2290.

[30] Toker C., B. Uzen, H. Canci, F.O. Ceylan. 2005. Effects of gamma irradiation on the shoot length of Cicer seeds. Radiat. Phys. Chem. 73. 365-367.

[31] Al-Salhi M, M.M. Ghannam, Al-Ayed, M.S. AlAyed, S.U. El-Kameesy, S. Roshdy. 2004. Effect of gamma irradiation on the biophysical and morphological properties of corn Nahrung. Mol. Nutri. Food Res. 48. 95-98.
[32] Dwimahyani, I., S. Widiarsih. 2010. The effects of gamma irradiation on the growth and propagation of in-vitro chrysanthemum shoot explants (cv. Yellow Puma). Atom Indonesia. 36. 45-49. 